\title{
PENGEMBANGAN PERANGKAT PEMBELAJARAN FISIKA SMA BERBASIS MODEL INKUIRI TERBIMBING UNTUK MENSTIMULUS KETERAMPILAN PROSES SAINS SISWA PADA MATERI LISTRIK DINAMIS
}

\author{
Rachmat Rizaldi \\ Dosen FKIP UISU \\ rachmat.r@fkip.uisu.ac.id
}

\begin{abstract}
ABSTRAK
Salah satu faktor rendahnya hasil belajar siswa adalah kurangnya keterampilan proses sains siswa dalam pembelajaran. Perangkat pembelajaran yang tersedia di sekolah belum sesuai kebutuhan siswa. Hal ini menuntut guru untuk mengembangkan perangkat pembelajaran berupa Rencana Pelaksanaan Pembelajaran (RPP), Lembar Kerja Siswa(LKS), Handout, dan penilaian yang dapat menstimulus keterampilan proses sains siswa. Salah satu model pembelajaran yang sesuai kebutuhan tersebut adalah model inkuiri. Penelitian ini bertujuan untuk mengembangkan perangkat pembelajaran berbasis model inkuiri terbimbing untuk menstimulus keterampilan proses sains siswa pada materi listrik dinamis dengan kriteria valid, praktis dan efektif. Penelitian ini merupakan penelitian pengembangan (Research and Development). Model pengembangan yang digunakan adalah 4-D terdiri dari tahap Define, Design, Development ,dan Dissiminate. Hasil analisis validasi perangkat pembelajaran yang telah dikembangkan berada pada kategori sangat valid dengan nilai 86,3\%. Analisis praktikalitas berdasarkan angket keterlaksanaan RPP dengan nilai 85,6\%, angket respon guru dengan nilai $84,08 \%$ dan angket respon siswa dengan nilai 75,6\% diperoleh bahwa perangkat sangat praktis. Hasil uji efektivitas dinyatakan bahwa perangkat pembelajaran yang dikembangkan efektif karena perangkat dapat meningkatkan kompetensi siswa pada kompetensi pengetahuan dengan nilai 78,7, sikap dengan nilai 75,4 dan keterampilan proses sainsnya dengan nilai 75,3. Dengan demikian, perangkat pembelajaran fisika berbasis model inkuiri terbimbing untuk menstimulus keterampilan proses sains siswa pada materi listrik dinamis sangat valid, sangat praktis dan efektif untuk diterapkan pada proses pembelajaran.
\end{abstract}

Kata kunci: Perangkat Pembelajaran, Inkuiri Terbimbing, Keterampilan Proses Sains, Listrik Dinamis.

\section{PENDAHULUAN}

Globalisasi menciptakan persaingan dan tantangan diberbagai bidang terutama bidang pendidikan. Berbagai usaha telah dilakukan pemerintah untuk menciptakan sumber daya manusia yang diharapkan dapat meningkatkan kualitas pendidikan. Usaha-usaha yang telah dilakukan, antara lain peningkatan kualitas guru dalam bentuk penataran-penataran, peningkatan mutu manajemen sekolah, peningkatan sarana dan prasarana pendidikan, pengembangan perangkat, metode, strategi, media pembelajaran, dan penyempurnaan kurikulum.

Penyempurnaan kurikulum 2013 memberikan kebebasan kepada guru untuk lebih kreatif dan inovatif mengajak siswa mengembangkan karakter atau keterampilan untuk mengikuti proses pembelajaran, dan menciptakan pembelajaran yang berkualitas. Pihak-pihak terkait lainnya seperti peneliti bidang pendidikan telah mengupayakan kemajuan dalam pendidikan di Indonesia. Sebagai contoh, penelitian yang dilakukan oleh Asyhari (2014) tentang pengembangan perangkat pembelajaran fisika SMA berbasis Inkuiri Terbimbing terintegrasi pendidikan karakter. Kemudian penelitian oleh Petri (2015) tentang pengembangan perangkat pembelajaran fisika SMA dengan strategi pembelajaran Inkuiri Terbimbing berbasis pendekatan saintifik untuk meningkatkan kompetensi belajar fisika.

Namun, semua harapan dari kurikulum 2013 belum terlihat hasil yang signifikan. Berdasarkan observasi yang dilakukan peneliti terhadap kegiatan pembelajaran fisika di SMA Negeri 1 Sungai Aur tanggal 30 September 2015 menggunakan kuisioner berupa angket kebutuhan siswa. Secara umum hasil analisis kebutuhan siswa disajikan pada Tabel 1. 
Tabel 1. Hasil Analisis Kebutuhan Siswa

\begin{tabular}{|c|l|c|}
\hline $\begin{array}{c}\text { No } \\
\text { pertanyaan }\end{array}$ & \multicolumn{1}{|c|}{ Permasalahan } & SMAN 1 Sungai Aur \\
\hline $1-3$ & $\begin{array}{l}\text { Siswa menganggap pelajaran Fisika } \\
\text { sulit dimengerti }\end{array}$ & $81,1 \%$ \\
\hline $4-6$ & $\begin{array}{l}\text { Siswa mampu memecahkan } \\
\text { permasalahan Fisika }\end{array}$ & $58,9 \%$ \\
\hline $7-16$ & $\begin{array}{l}\text { Siswa mampu mengembangkan } \\
\text { keterampilan proses sainsnya }\end{array}$ & $73,9 \%$ \\
\hline $17-22$ & $\begin{array}{l}\text { Siswa menyenangi metode belajar } \\
\text { dalam kelompok }\end{array}$ & $78,6 \%$ \\
\hline $23-29$ & $\begin{array}{l}\text { Siswa menyenangi bahan ajar di } \\
\text { sekolah }\end{array}$ \\
\hline 30 & $\begin{array}{l}\text { Siswa kurang menyukai tugas-tugas } \\
\text { yang diberikan guru di sekolah }\end{array}$ \\
\hline
\end{tabular}

Dengan memperhatikan hasil analisis kebutuhan siswa di SMAN 1 Sungai Aur pada Tabel 1 dapat diketahui bahwa permasalahan dalam pembelajaran Fisika diantaranya masih terdapat banyak siswa yang menganggap pelajaran Fisika sulit dimengerti. Hal ini terlihat dari persentase siswa yang menganggap pelajaran Fisika sulit dimengerti sebanyak $81,1 \%$. Permasalahan ini terlihat dari sedikitnya persentase siswa yang mampu memecahkan permasalahan Fisika berupa soal-soal Fisika. Persentase siswa yang mampu memecahkan permasalahan Fisika diketahui sebanyak 58,9\%. Untuk lebih jelasnya dapat dilihat pada Lampiran 5. Hal ini mempengaruhi hasil belajar siswa dalam memahami materi fisika dengan baik.

Berdasarkan hasil wawancara dengan guru Fisika di sekolah diketahui bahwa materi listrik dinamis dianggap cukup sulit bagi siswa. Hal ini ditunjukkan masih banyak siswa yang belum mencapai kriteria ketuntasan minimum (KKM), terlihat dari nilai rata-rata ulangan harian siswa kelas X pada materi Listrik Dinamis tahun ajaran 2014/2015 di SMA Negeri 1 Sungai Aur yang masih rendah. Nilai rata-rata UH fisika pada materi Listrik Dinamis masih dibawah KKM yang bernilai 75. Untuk lebih jelasnya dapat dilihat pada Tabel 2.

Tabel 2. Nilai Rata-rata Ulangan Harian Siswa

Tahun Ajaran 2014/2015

\begin{tabular}{|c|c|c|c|c|c|}
\hline \multirow{2}{*}{ Kelas } & \multirow{2}{*}{$\begin{array}{c}\text { Jmlah } \\
\text { Peserta } \\
\end{array}$} & \multicolumn{2}{|c|}{ Tidak Tuntas } & \multicolumn{2}{|c|}{ Tuntas } \\
\cline { 3 - 6 } & Jumlah & \% & Jumlah & \% \\
\hline X MIA 1 & 32 & 20 & 62.50 & 12 & 37.50 \\
\hline X MIA 2 & 32 & 19 & 59.38 & 13 & 40.63 \\
\hline X MIA 3 & 32 & 19 & 59.38 & 13 & 40.63 \\
\hline X MIA 4 & 32 & 17 & 53.13 & 15 & 46.88 \\
\hline X MIA 5 & 32 & 18 & 56.25 & 14 & 43.75 \\
\hline X MIA 6 & 32 & 21 & 65.62 & 11 & 34.37 \\
\hline
\end{tabular}

(Sumber: Guru fisika kelas X SMAN 1 Sungai Aur)

Tabel 2 di atas memperlihatkan bahwa persentase nilai UH siswa yang tidak tuntas lebih banyak daripada siswa yang tuntas pada materi Listrik Dinamis. Hal ini dipengaruhi juga oleh tujuan materi yang digunakan dalam pembelajaran. Dari hasil analisis materi dan tujuan pembelajaran Listrik Dinamis diperoleh jumlah fakta dengan persentase 30,4\%, konsep dengan persentase $32,6 \%$, dan prinsip dengan persentase $36,9 \%$. Hasil ini menunjukkan bahwa materi Listrik Dinamis didominasi oleh konsep dan prinsip. Agar siswa dapat memahami konsep dan prinsip-prinsip yang ada, dibutuhkan keterampilan proses sains siswa. Dari hasil analisis angket siswa menunjukkan bahwa secara umum keterampilan proses sains yang dimiliki siswa di 
SMAN 1 Sungai Aur dengan persentase 42,7\%. Hasil analisis keterampilan proses sains siswa di SMAN 1 Sungai Aur digambarkan dalam gambar 1 berikut.

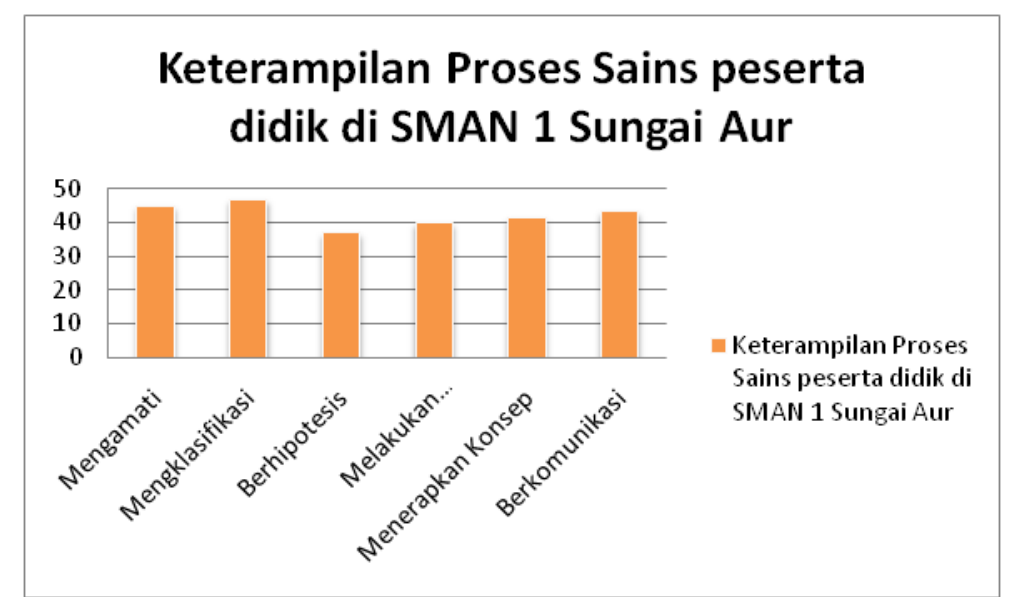

Gambar 1. Keterampilan Proses Sains Siswa di SMAN 1 Sungai Aur

Gambar 1 menunjukkan bahwa keterampilan proses sains siswa masih rendah. Persentase yang diperoleh siswa pada aspek mengamati sebesar 45,1\%, mengklasifikasi sebesar $47 \%$, berhipotesis sebesar 37\%, merancang percobaan sebesar 40\%, menerapkan konsep sebesar 41,5\%, dan berkomunikasi sebesar 43,4\%. Hal ini terjadi karena di sekolah belum mengintegrasikan keterampilan proses sains ke dalam substansi pembelajarannya.

Keterampilan proses sains siswa erat kaitannya dengan bahan ajar yang dirancang guru dalam pembelajaran. Hasil wawancara dengan guru diketahui bahwa belum ada bahan ajar yang tepat untuk menstimulus keterampilan proses sains siswa. Guru mengalami kesulitan dalam mengembangkan bahan ajar yang sesuai dengan kebutuhan siswa. Siswa juga kurang menyenangi bahan ajar yang digunakan di sekolah. Hal ini terlihat dari sedikitnya siswa yang menyenangi bahan ajar di sekolah dengan persentase 48,6\%. Berdasarkan pengamatan di sekolah bahan ajar yang digunakan oleh guru masih berasal dari penerbit berupa buku ajar dan LKS sehingga kurang memperhatikan kebutuhan siswa dalam belajar.

Penjabaran pada bahan ajar di sekolah masih umum terlihat pada penyajian ringkasan materi dan tidak adanya dicantumkan indikator dan tujuan pembelajaran secara jelas. Bahan ajar yang digunakan belum memperlihatkan langkah-langkah model pembelajaran yang mengarahkan kepada keterampilan proses sains siswa. Kegiatan pembelajaran pada bahan ajar langsung diarahkan untuk pengerjaan soal-soal hitung tanpa diberikan ruang bagi siswa untuk mengeksplorasi pengetahuan untuk menemukan jawaban dari permasalahan. Keadaan ini berdampak kepada perkembangan keterampilan proses sains siswa sehingga siswa kurang mampu dalam mengaplikasikan konsep yang dipelajari dalam pemecahan masalah yang ditandai dengan hasil belajar yang belum memuaskan.

Tugas-tugas yang diberikan guru di sekolah juga masih belum sesuai dengan kebutuhan siswa. Hal ini terlihat dari banyaknya siswa yang menyatakan kurang menyukai tugas-tugas yang diberikan guru di sekolah dengan persentase $73 \%$. Hasil analisis tugas di sekolah terdapat berbagai bentuk tugas yang dikerjakan siswa. Tugas-tugas tersebut belum menunjang ketercapaian kompetensi siswa. Kompetensi siswa terbagi tiga yaitu pengetahuan, sikap dan keterampilan. Persentase untuk setiap kompetensi berdasarkan tugas yang diberikan guru di sekolah pada materi listrik dinamis adalah untuk kompetensi pengetahuan dengan persentase $33,3 \%$, untuk kompetensi sikap dengan persentase 16,6\% dan kompetensi keterampilan dengan persentase $8,3 \%$.

Selain itu, kebanyakan siswa lebih menyukai jenis metode pembelajaran berkelompok. Hal ini terlihat dari persentase siswa menyenangi metode belajar dalam kelompok di sekolah sebanyak 73,9\% . Dengan pembelajaran secara berkelompok siswa dapat mengembangkan dan mengemukakan ide-ide kreatifnya secara bebas. Siswa menganggap pembelajaran secara 
berkelompok dapat meningkatkan keterampilan proses sainsnya memecahkan permasalahan Fisika. Siswa juga dapat terlibat aktif dalam setiap kegiatan berkelompok. Dengan pembelajaran berkelompok siswa dapat meningkatkan kompetensinya dengan baik.

Dari hasil analisis kebutuhan di atas, maka guru perlu mengembangkan perangkat pembelajaran yang sesuai dengan tuntutan kurikulum 2013. Perangkat pembelajaran yang dikembangkan berupa Rencana Pelaksanaan Pembelajaran (RPP), Handout, Lembar Kerja Siswa (LKS), dan penilaian.

Untuk lebih mengaktifkan keterampilan proses sains siswa dalam menemukan konsep, bentuk model pembelajaran yang digunakan hendaknya mampu mengarahkan pada kreativitas dalam menyelesaikan masalah. Salah satu model pembelajaran yang dianggap sesuai dengan keadaan di lapangan dan mampu meningkatkan kemampuan berpikir dan ketrampilan proses siswa adalah model Inkuiri. Menurut Yunus Abidin (2014:154)" Langkah-langkah model inkuiri dimulai dari menetapkan masalah, merumuskan hipotesis, melaksanakan penelitian/eksperimen, menganalisis data, menguji hipotesis, membuat simpulan dan menyajikan hasil". Model Inkuiri yang sesuai digunakan dalam perangkat pembelajaran adalah model Inkuiri terbimbing.

Salah satu materi yang diambil peneliti berdasarkan hasil analisis materi yang dilakukan adalah materi Listrik Dinamis. Materi Listrik Dinamis terkait langsung dalam kehidupan nyata manusia sehingga akan memudahkan guru untuk memberikan contoh kepada siswa tentang materi ini. Pada materi ini membutuhkan keterampilan proses siswa dengan melakukan percobaan.

Berdasarkan uraian di atas, maka perlu dilakukan penelitian pengembangan perangkat pembelajaran fisika SMA berbasis model Inkuiri terbimbing untuk menstimulus keterampilan proses sains siswa.

Rumusan masalah yang dikembangkan dalam penelitian ini adalah sebagai berikut.

1. Bagaimanakah mengembangkan perangkat pembelajaran Fisika SMA berbasis model inkuiri terbimbing yang dapat menstimulus keterampilan proses sains siswa dengan kriteria valid, praktis, dan efektif?

2. Bagaimanakah menerapkan perangkat pembelajaran Fisika SMA berbasis model inkuiri terbimbing yang dapat menstimulus keterampilan proses sains siswa dengan kriteria valid, praktis, dan efektif di kelas yang lain?

\section{METODE PENELITIAN}

Jenis penelitian ini adalah penelitian pengembangan (Research \& Development). Model pengembangan 4-D (Define, Design, Develop, dan Disseminate). Subjek uji coba produk adalah siswa kelas X SMA N 1 Sungai Aur.

Proses pengembangan dimulai dari tahap pendefenisian yang meliputi analisis kurikulum, materi, siswa, dan tugas. Setelah itu tahap merancang perangkat pembelajaran yang terdiri dari: RPP, LKS, Handout dan penilaian. Selanjutnya tahap pengembangan perangkat pembelajaran sesuai dengan rancangan yang dibuat, melakukan uji validitas dan uji praktikalitas serta melakukan uji coba kepada siswa untuk melihat efektivitas penggunaan perangkat pembelajaran. Setelah diperoleh perangkat pembelajaran yang valid, praktis dan efektif maka perangkat pembelajaran tersebut sudah dapat disebarkan ke kelas lain, sekolah lain atau guru lain untuk digunakan dalam proses pembelajaran.

\section{HASIL PENELITIAN}

Proses pengembangan dimulai dari tahap pendefinisian yang meliputi analisis kurikulum, analisis materi, dan analisis siswa. Setelah itu dilanjutkan dengan tahap pengembangan perangkat pembelajaran yang meliputi RPP, Handout, LKS, dan penilaian. Kemudian perangkat tersebut divalidasi oleh tiga orang pakar/dosen pascasarjana UNP dan dua orang praktisi/guru fisika di SMAN 1 Sungai Aur. 
Sebelum melakukan validasi perangkat, terlebih dahulu dilakukan penilaian terhadap lembar validasi oleh pakar. Setelah lembar validasi dinyatakan valid maka dilakukan validasi terhadap perangkat pembelajaran yang dikembangkan. Semua instrumen yang dinyatakan valid digunakan untuk mengukur tingkat validitas dari perangkat pembelajaran. Hal ini dibuktikan dengan nilai rata-rata instrumen validasi berada pada rentang 84,7\% sampai 88,8\% yang berada pada kategori sangat valid. Dengan demikian lembar validasi perangkat pembelajaran Fisika dapat digunakan untuk memvalidasi perangkat pembelajaran yang dikembangkan.

Penilaian instrumen validasi lembar praktikalitas berada pada kategori sangat valid. Penilaian ini memiliki nilai $87,1 \%$ sampai $88,6 \%$ dengan rata-rata $87,7 \%$ dengan kategori sangat valid. Berdasarkan data tersebut maka dapat disimpulkan bahwa lembar validasi praktikalitas dapat digunakan.

Hasil analisis validasi RPP oleh validator divalidasi berdasarkan kelayakan isi, konstruksi, dan bahasa. didapatkan hasil antara $75 \%$ sampai 92,7\%, sehingga diperoleh ratarata 83,2 \%. Angka tersebut menyatakan bahwa RPP berada dalam kategori sangat valid. Hasil ini menunjukkan bahwa RPP dapat diujicobakan.

Hasil analisis validasi Handout oleh validator divalidasi berdasarkan kelayakan isi, konstruksi, dan bahasa didapatkan hasil antara $82,9 \%$ sampai $96,4 \%$, sehingga diperoleh ratarata $88,3 \%$. Angka tersebut menyatakan bahwa Handout berada dalam kategori sangat valid. Hasil ini menunjukkan bahwa Handout dapat diujicobakan.

Hasil analisis validasi LKS oleh validator divalidasi berdasarkan kelayakan isi, konstruksi, dan bahasa didapatkan hasil antara $80,2 \%$ sampai $92,9 \%$, sehingga diperoleh ratarata $85,5 \%$. Angka tersebut menyatakan bahwa LKS berada dalam kategori sangat valid. Hasil ini menunjukkan bahwa LKS dapat diujicobakan.

Hasil analisis validasi Penilaian oleh validator divalidasi berdasarkan kelayakan isi, konstruksi, dan bahasa didapatkan hasil antara $84,5 \%$ sampai $95,0 \%$, sehingga diperoleh ratarata $88,2 \%$. Angka tersebut menyatakan bahwa Penilaian berada dalam kategori sangat valid. Hasil ini menunjukkan bahwa Penilaian dapat diujicobakan.

Selanjutnya dilakukan uji praktikalitas terhadap perangkat pembelajaran yang dikembangkan. Uji praktikalitas diperoleh dari hasil penilaian terhadap keterlaksanaan RPP untuk setiap kali pertemuan, hasil penilaian dari perangkat pembelajaran (angket respon guru), dan hasil penilaian Handout dan LKS (angket respon siswa). Hasil keterlaksanaan RPP untuk setiap kali pertemuan berada pada kategori sangat praktis, baik dilihat dari tahap pendahuluan, kegiatan inti, maupun penutup. Selama kegiatan berlangsung diperoleh rata-rata 85,625 jika disesuaikan dengan rentang penilaian berada pada interval 81-100 dengan kategori sangat praktis.

Penilaian guru terhadap perangkat pembelajaran Fisika berbasis model pembelajaran Inkuiri Terbimbing yang telah dikembangkan (angket respon guru) memiliki nilai rata-rata 84,08. Berdasarkan interval kategori praktikalitas nilai tersebut berada pada interval 81-100 dengan kategori sangat praktis.

Hasil analisis respon siswa terhadap Handout dan LKS yang telah dikembangkan dengan nilai rata-rata 75,695 yang berada pada interval 61-80 dengan kategori praktis.

Untuk mengetahui efektivitas dari perangkat pembelajaran yang dikembangkan diperoleh dari hasil analisis penilaian pengetahuan, penilaian sikap, dan penilaian keterampilan proses sains siswa.

\section{a. Hasil Penilaian Pengetahuan}

Nilai rata-rata hasil belajar siswa untuk kompetensi pengetahuan berada pada kategori baik. Pada pertemuan pertama, sebanyak 23 siswa tuntas dan 7 orang belum tuntas karena nilainya di bawah KKM $(<75)$. Jumlah siswa yang tidak tuntas pada pertemuan II sebanyak 13 orang, Hal ini mengalami penurunan dikarenakan siswa yang kurang fokus selama pembelajaran sebab di sekolah sedang persiapan acara perpisahan siswa kelas 3 dan ujian Nasional. Beberapa siswa banyak terlibat dalam persiapan seperti menjadi panitia acara perpisahan dan juga membersihkan ruangan kelas untuk pelaksanaan Ujian Nasional. Hal ini menyebabkan siswa 
menjadi kurang berkonsentrasi terhadap pelajaran. Namun pada pertemuan III jumlah siswa yang tidak tuntas sebanyak 5 orang, dan pertemuan IV sebanyak 2 orang siswa. Untuk lebih jelasnya dapat dilihat pada Gambar 2.

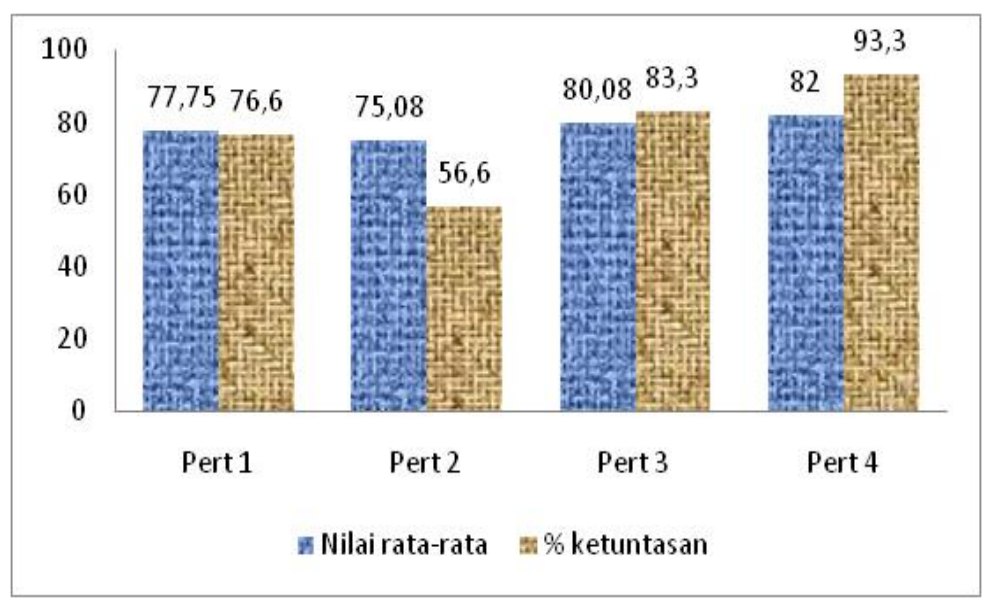

Gambar 2. Grafik Kompetensi Pengetahuan

Berdasarkan Gambar 2 terlihat bahwa nilai rata-rata dan persentase ketuntasan siswa pada kompetensi pengetahuan tidak selalu mengalami peningkatan. Namun, secara umum nilai ratarata siswa dari empat pertemuan berada di atas nilai KKM yaitu 75. Nilai rata-rata selama empat kali pertemuan adalah 78,72 dengan persentase ketuntasan 77,45\%. Hasil tersebut menunjukkan bahwa perangkat pembelajaran fisika berbasis model inkuiri terbimbing efektif dapat meningkatkan hasil belajar siswa pada kompetensi pengetahuan.

\section{b. Hasil Penilaian Sikap}

Sikap siswa berada dalam kategori baik dengan nilai rata-rata kelas sebesar 75,42. Hasil ini menunjukkan perangkat pembelajaran yang dikembangkan efektif digunakan dalam pembelajaran untuk meningkatkan hasil belajar siswa pada kompetensi sikap. Mulai dari pertemuan I sampai pertemuan IV. Hasil analisis penilaian sikap digambarkan dalam bentuk grafik pada Gambar 3.

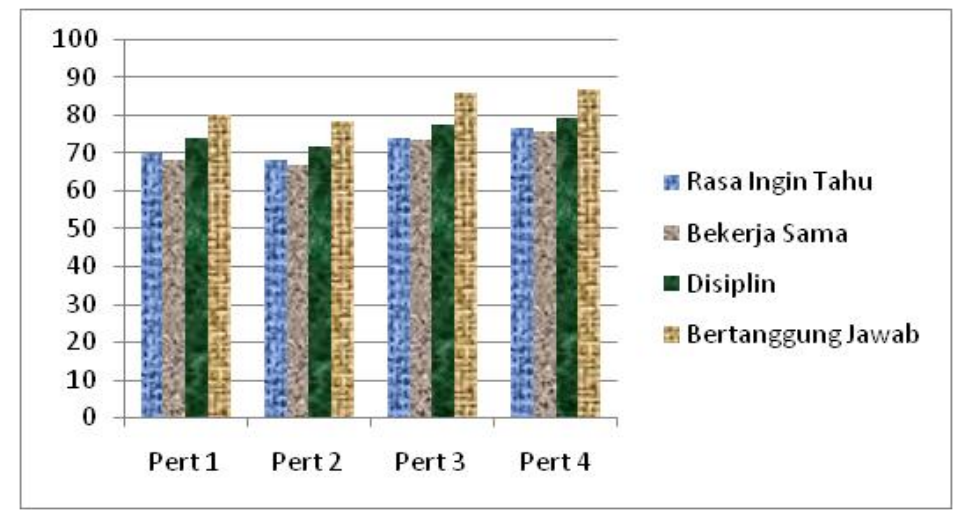

Gambar 3. Grafik Penilaian Sikap

Gambar 3 terlihat bahwa sikap siswa tidak selalu mengalami peningkatan pada setiap pertemuan. Namun secara umum hasil ini menggambarkan bahwa perangkat pembelajaran yang digunakan pada materi listrik dinamis efektif dalam meningkatkan hasil belajar siswa pada kompetensi sikap.

c. Hasil penilaian Keterampilan Proses Sains 
Hasil belajar siswa pada kompetensi keterampilan proses sains diambil dari kegiatan siswa dalam melakukan kegiatan praktikum. Secara ringkas dapat dilihat pada Tabel 3.

Tabel 3. Hasil Penilaian Keterampilan Proses Sains

\begin{tabular}{|l|c|c|c|c|c|}
\hline \multirow{2}{*}{\begin{tabular}{c}
\multirow{2}{*}{$\begin{array}{c}\text { Aspek } \\
\text { Pengamatan }\end{array}$} \\
\cline { 2 - 5 }
\end{tabular}} & \multicolumn{4}{|c|}{ Pertemuan } & \multirow{2}{*}{ Rata-rata } \\
\cline { 2 - 5 } Mengamati & 71,6 & 69,1 & 78,3 & 80 & 74,8 \\
\hline Mengklasifikasi & 70,8 & 68,3 & 76,6 & 77,5 & 73,3 \\
\hline $\begin{array}{l}\text { Merencanakan } \\
\text { percobaan }\end{array}$ & 77,5 & 72,5 & 79,1 & 80,8 & 77,5 \\
\hline $\begin{array}{l}\text { Berhipotesis } \\
\text { Menerapkan } \\
\text { konsep }\end{array}$ & 78,3 & 75 & 80,8 & 81,6 & 79,0 \\
\hline Berkomunikasi & 70,8 & $\mathbf{6 8 , 3}$ & 76,6 & 80 & 74,0 \\
\hline Rata-rata (\%) & $\mathbf{7 3 , 6}$ & $\mathbf{7 0 , 6}$ & $\mathbf{7 7 , 6}$ & $\mathbf{7 9 , 4}$ & $\mathbf{7 5 , 3}$ \\
\hline
\end{tabular}

Berdasarkan Tabel 3 memperlihatkan semua indikator yang diobservasi pada kegiatan praktikum berada pada kategori baik. Nilai hasil belajar kompetensi keterampilan pada semua aspek mendapat nilai rata-rata 75,3. Jika berpedoman pada tabel kategori efektif, maka nilai rata-rata ini berada pada interval 61-80 dengan kategori baik. Hasil ini menunjukkan bahwa perangkat pembelajaran fisika berbasis model pembelajaran inkuiri terbimbing efektif dapat menstimulus keterampilan proses sains siswa.

Untuk melihat hasil penilaian keterampilan proses sains tiap-tiap pertemuan pada setiap indikatornya yang terdiri dari mengamati, mengklasifikasi, berhipotesis, merencanakan percobaan, dan berkomunikasi digambarkan pada Gambar 4.

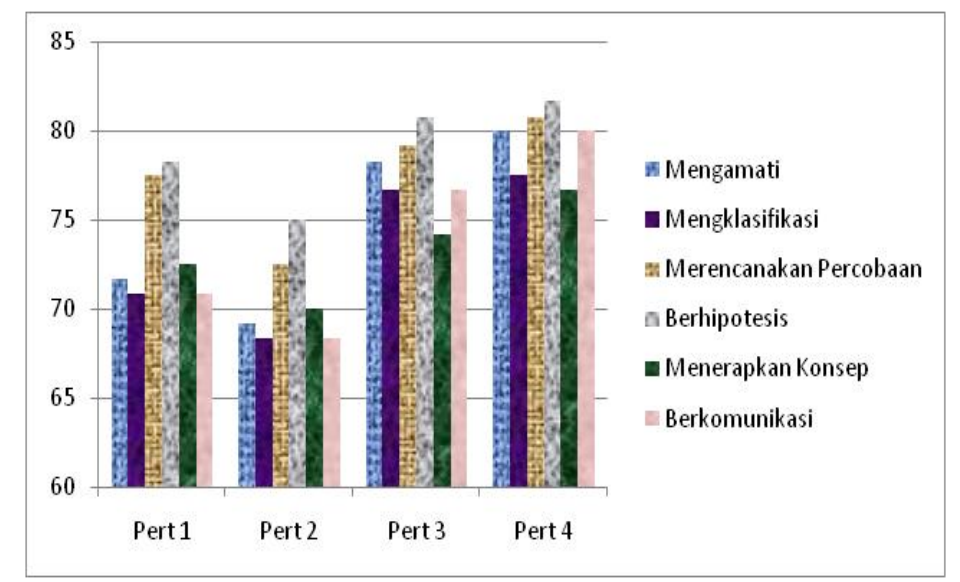

Gambar 4. Grafik Nilai Kompetensi Keterampilan Kelas Uji Coba

Berdasarkan Gambar 4 terlihat bahwa pada setiap pertemuan menunjukkan tiap-tiap indikator keterampilan proses sains siswa tidak selalu mengalami peningkatan. Namun secara umum hasil ini menggambarkan bahwa perangkat pembelajaran yang digunakan efektif dapat menstimulus keterampilan proses sains siswa pada kompetensi keterampilan. 


\section{PEMBAHASAN}

Hasil penelitian ini menunjukkan bahwa perangkat pembelajaran fisika SMA berbasis model inkuiri terbimbing berada pada kriteria valid, praktis dan efektif digunakan dapat menstimulus keterampilan proses sains siswa.

Perangkat pembelajaran dinyatakan valid oleh validator karena perangkat sudah berbasis model pembelajaran inkuiri terbimbing, seperti di RPP pada kegiatan pembelajaran menggunakan langkah kegiatan model inkuiri terbimbing. Pada Handout dan LKS yang dibuat juga menggunakan langkah model pembelajaran inkuiri terbimbing.

Suatu instrumen dikatakan valid bila instrumen tersebut dapat digunakan untuk mengukur apa yang seharusnya diukur (Sugiyono, 2010:414). Validitas yang dilakukan meliputi: validitas isi, validitas konstruk, dan validitas bahasa. Validitas isi dinyatakan valid oleh validator karena perangkat pembelajaran yang dikembangkan telah sesuai dengan materi yang seharusnya disajikan. Untuk menguji validitas konstruksi dapat digunakan pendapat para ahli (Riduwan,2009:87). Sedangkan validitas bahasa menunjukan komponen bahasa yang digunakan sesuai dengan kaidah bahasa Indonesia yang baik dan benar, kejelasan informasi dan pemanfaatan bahasa secara efektif.

Kepraktisan perangkat pembelajaran juga dapat dilihat dari angket respon guru dan respon siswa. Kriteria suatu perangkat pembelajaran yang praktis adalah keterpakaian dan keterlaksanaannya(Elnianti dalam dimyanti dan mudjiono,2006). Keterpakaian artinya guru dan siswa dapat menggunakan perangkat yang dibuat, sedangkan keterlaksanaan mengacu pada perangkat yang dapat digunakan guru untuk menyampaikan topik-topik fisika dalam kondisi pembelajaran.

Hasil angket respon guru dapat diketahui bahwa persentase rata-rata tanggapan guru terhadap RPP, Handout, LKS, dan instrumen penilaian yang digunakan adalah $84,4 \% ; 85,7 \%$; $85 \%$; dan $81,25 \%$ yang berada pada kategori sangat praktis.

Selanjutnya, hasil angket respon siswa juga memperlihatkan praktikalitas perangkat pembelajaran berada pada kategori praktis dengan persentase praktikalitas untuk Handout dan LKS yaitu 75,8\% dan 75,59\%. Secara umum dari hasil analisis data ini dapat disimpulkan bahwa dengan menggunakan perangkat pembelajaran berbasis model pembelajaran inkuiri terbimbing pada materi Listrik Dinamis, siswa dapat termotivasi mengikuti pelajaran. Perangkat ini membantu siswa untuk memecahkan permasalah Fisika karena siswa langsung dilibatkan dalam mengkonstruksi pengetahuan mereka.

Efektivitas perangkat pembelajaran dilihat berdasarkan hasil belajar siswa pada kompetensi pengetahuan, sikap, dan keterampilan. Hasil analisis penilaian pengetahuan, sikap, dan keterampilan proses sains siswa selama empat kali pertemuan tidak selalu mengalami peningkatan. Siswa pada pertemuan kedua kurang memperhatikan pembelajaran, banyak siswa yang kurang konsentrasi sehingga hasil belajar siswa pada pertemuan kedua rendah. Menurut Djamarah(2008)"Konsentrasi adalah pemusatan fungsi jiwa terhadap suatu objek seperti konsentrasi pikiran, perhatian dan sebagainya". Dalam belajar dibutuhkan konsentrasi dalam bentuk perhatian yang terpusat pada suatu pelajaran. Konsentrasi belajar siswa dapat dipengaruhi oleh faktor lingkungan, modalitas belajar dan psikologi(Nugroho,2007).

Konsentrasi belajar dapat terganggu karena dipengaruhi oleh beberapa faktor. Menurut Nugroho(2007)"Faktor yang menyebabkan gangguan konsentrasi belajar siswa yaitu tidak adanya motivasi diri, suasana lingkungan belajar yang tidak kondusif dan kondisi kesehatan siswa”. Siswa yang kurang fokus dalam belajar, kurang memperhatikan pelajaran, dan berbicara dengan teman dalam pembelajaran akan mengakibatkan suasana lingkungan belajar yang kurang kondusif, akibatnya siswa kurang berkonsentrasi dalam belajar sehingga hasil belajar siswa menjadi rendah.

\section{SIMPULAN, SARAN, DAN IMPLIKASI}

Berdasarkan hasil penelitian di atas dapat disimpulkan sebagai berikut. 
1. Dihasilkan Perangkat pembelajaran fisika berbasis model inkuiri terbimbing untuk menstimulus keterampilan proses sains siswa dengan langkah-langkah sebagai berikut:

a. Pada tahap define disimpulkan bahwa diperlukan suatu pengembangan dengan menggunakan model pembelajaran Inkuiri terbimbing pada materi listrik dinamis untuk menstimulus keterampilan proses sains siswa.

b. Pada tahap design disimpulkan bahwa perangkat pembelajaran fisika berbasis model inkuiri terbimbing sesuai dengan panduan isi yang mengacu pada aspek-aspek model pembelajaran Inkuiri terbimbing, dan pendekatan sainstifik, panduan konstruksi yang mengacu pada standar isi, proses, dan penilaian dalam kurikulum 2013, dan panduan bahasa yang mengikuti BSNP dan kaidah Ejaan Bahasa Indonesia.

c. Pada tahap development diperoleh nilai validitas, praktikalitas, dan efektivitas sebagai berikut

1) Persentase validitas perangkat pembelajaran fisika berbasis model inkuiri terbimbing yaitu $86,3 \%$ berkategori sangat valid.

2) Praktikalitas hasil angket keterlaksanaan RPP dapat diketahui persentase rataratanya adalah $85,6 \%$ yang berada pada kategori sangat praktis. Hasil angket respon guru dapat diketahui persentase rata-rata adalah $84,08 \%$ yang berada pada kategori sangat praktis. Hasil angket respon siswa dapat diketahui persentase ratarata adalah $75,6 \%$ yang berada pada kategori praktis.

3) Efektivitas perangkat pembelajaran yang dikembangkan efektif $(78,7)$ untuk aspek pengetahuan, $(75,4)$ untuk aspek sikap, dan $(75,3)$ untuk aspek keterampilan proses sains.

2. Pada tahap disseminate di kelas yang berbeda dan sekolah yang berbeda menunjukkan peningkatan hasil kompetensi pengetahuan, sikap, dan keterampilan proses sains siswa pada setiap pertemuannya dengan nilai rata-rata adalah 79,4 untuk aspek pengetahuan, 75,7 untuk aspek sikap, dan 76,7 untuk aspek keterampilan proses sainsnya.

Adapun implikasi dari penelitian ini adalah sebagai berikut.

1. Bagi siswa, perangkat pembelajaran Fisika berbasis model pembelajaran inkuiri terbimbing dapat meningkatkan kompetensi siswa. Baik kompetensi pengetahuan, sikap, dan keterampilan proses sainsnya. Selain itu, perangkat pembelajran ini dapat juga mengaktifkan dan mengoptimalkan potensi siswa.

2. Bagi guru, perangkat pembelajaran Fisika berbasis model pembelajaran inkuiri terbimbing dapat digunakan guru sebagai perangkat di dalam kegiatan pembelajaran terutama pada mata pelajaran Fisika. Selain itu, juga dapat dijadikan acuan dalam upaya merencanakan kegiatan pembelajaran yang lain pada Kurikulum 2013.

3. Bagi peneliti lain, perangkat ini dapat dijadikan sebagai bahan rujukan ataupun perbandingan sebagai upaya dalam mengembangkan perangkat pembelajaran yang lebih baik lagi kedepannya.

Berdasarkan pengembangan yang telah dilakukan, adapun saran yang perlu diperhatikan dan diperbaiki kedepannya adalah sebagai berikut:

1. Peneliti hanya mengambil satu sekolah sebagai uji coba perangkat. Untuk mendapatkan hasil yang lebih maksimal sebaiknya uji coba perangkat dilakukan dibeberapa kelas dan sekolah sehingga dapat diketahui tingkat kepraktisan dan keefektifan yang lebih baik dari perangkat pembelajaran yang dikembangkan.

2. Guru hendaknya mempertimbangkan alokasi waktu dalam kegiatan pembelajaran supaya setiap kegiatan yang telah dibuat dan direncanakan dapat terlaksana dengan baik.

3. Peneliti lanjut diharapkan dapat melakukan pengembangan perangkat pada materi fisika yang berbeda sehingga dapat membantu terciptanya pembelajaran yang interaktif, menyenangkan dan memotivasi siswa untuk berpartisipasi aktif dalam kegiatan pembelajaran. 


\section{DAFTAR PUSTAKA}

1. Asyhari, Ardian., dkk. 2014. Pengembangan Perangkat Pembelajaran Fisika Sma Berbasis Inkuiri Terbimbing Terintegrasi Pendidikan Karakter. http://jurnal.fkip.uns.ac.id/index.php/sains. ISSN: 2252-7893, Vol 3, No. I, 2014 (hal 62-75).

2. Djamarah. 2008. Strategi Belajar Mengajar. Jakarta: Rineka Cipta.

3. Dimyati dan Mudjiono. 2006. Belajar dan Pembelajaran. Jakarta : PT. Rineka Cipta.

4. Nugroho. 2007. Penerapan model pembelajaran conceptual understanding procedures untuk meningkatkan curiosty dan pemahaman konsep siswa. Semarang:Unnes.

5. Petri. 2015. Pengembangan Perangkat Pembelajaran Fisika SMA dengan Startegi Inkuiri Terbimbing Berbasis Pendekatan Scientifik pada Materi Suhu, Kalor, dan Perpindahan Kalor. tesis tidak diterbitkan. Padang: Program Pascasarjana Universitas Negeri Padang.

6. Riduwan. 2009. Metode Teknik Menyususn Tesis. Bandung : Alfabeta

7. Sugiyono. 2010. Metode penelitian kuantitatif kualitatif dan $r \& d$. Bandung: Alfabeta.

8. Yunus Abidin. 2014. Desain Sistem Pembelajaran dalam Konteks Kurikulum 2013. Bandung. Refika Aditama. 